Www.jmscr.igmpublication.org

Impact Factor 5.84

Index Copernicus Value: 83.27

ISSN (e)-2347-176x ISSN (p) 2455-0450

crossref DOI: _https://dx.doi.org/10.18535/jmscr/v5i7.160

Journal Of Medical Science And Clinical Research

IGM Publication

An Official Publication of IGM Publication

\title{
Relative Assessment of Ketamine Nebulisation and Ketamine Gargle in Attenuating Post-Operative Sore Throat
}

\begin{abstract}
Author
Dr Rajeev Kumar

Assistant Professor, Department of Anesthesia, Shri Ramkrishna Institute of Medical Sciences \& Sanaka Hospitals, Durgapur, WB, India

Corresponding Author

Dr Rajeev Kumar

Assistant Professor, Department of Anesthesia, Shri Ramkrishna Institute of Medical Sciences \& Sanaka Hospitals, Durgapur, WB, India

\section{ABSTRACT}

Sore throat is a utmost perceived morbidity following tracheal intubation in the post operative period. This study is planned with the aim to compare ketamine nebulisation with ketamine gargle to see the effectiveness of nebulisation over gargle in reducing the incidence and severity of post operative sore throat.

The data from the 200 patients were collected and presented here. 100 patients from Group A received $30 \mathrm{ml}$ of gargled ketamine solution. 100 patients from Group B received nebulised ketamine.

The results of the study were promising and revealed that Pre-operative ketamine nebulisation is comparable with ketamine gargle in reducing the incidence and severity of post-operative sore throat.

Keywords: General anaesthesia, Ketamine gargle, Ketamine nebulisation, Post-operative sore throat, Endotracheal intubation etc.
\end{abstract}

\section{INTRODUCTION}

Postoperative sore throat is a common occurrence following general anaesthesia and, although clinicians often regard it as a relatively minor complication, patients perceive avoidance as being of great importance. Instrumentation of the airway is an inherent risk factor for the development of this common complication, yet a number of techniques can reduce the incidence. We performed a systematic review in order to assess the risk factors that increase the likelihood of postoperative sore throat in adults and children and the efficacy of interventions designed to reduce its incidence ${ }^{[1]}$.
It is not uncommon for patients to complain of a "sore throat" after surgery that requires intubation. Despite variations in the degree of difficulty of intubation, there seems to be no correlation between attempts or duration of intubation and the degree (if any) of sore throat. In most instances, the patient makes the complaint immediately after surgery.

On occasion, however, the patient makes no comment until a few days after surgery. Despite the delay in onset of symptoms, this pharyngitis is still often blamed on the intubation process. 


\section{METHODOLOGY}

The study is conducted in Shri Ramkrishna Institute of Medical Sciences \& Sanaka Hospitals, Durgapur in Surgery department. The approval of ethical committee had been taken along with the consent from the patients were also taken. Total 200 patients having are group of 20-60 year were enrolled in to the study.

Patients undergoing elective surgeries under general anaesthesia in supine position, lasting up to 2 hours were included. Patients with history of pre-operative sore throat, asthma, COPD, smoking, recent non-steroidal antiinflammatory drug intake, those who required more than 1 attempt of intubation and in whom intubation time taken was greater than 20 seconds were excluded from the study.

The selected patients were divided in two study groups.

Group A includes (gargled ketamine) received $30 \mathrm{ml}$ of gargle solution containing $1 \mathrm{ml}$ ketamine $50 \mathrm{mg}$ in $29 \mathrm{ml}$ of normal saline by the operation theatre nurse. Patients were asked to gargle for 30 sec in 2 divided parts as to prevent chances of swallowing the large volume.

In Group B includes (nebulised ketamine) patients received $1 \mathrm{ml}$ ketamine $50 \mathrm{mg}$ in $4 \mathrm{ml}$ of normal saline for nebulisation for $15 \mathrm{~min}$ through the wall mounted oxygen source (8L, 50PSI).

\section{RESULTS \& DISCUSSION}

The data from the 200 patients were collected and presented here. 100 patients from Group A received $30 \mathrm{ml}$ of gargled ketamine solution. 100 patients from Group B received nebulised ketamine. The age distribution, sex distributions, weight and duration of anaesthesia is presented as below in table number 1 .

\begin{tabular}{|c|c|c|}
\hline Groups & $\begin{array}{c}\text { A: Gargled } \\
\text { Ketamine }\end{array}$ & $\begin{array}{c}\text { B: Nebulised } \\
\text { Ketamine }\end{array}$ \\
\hline Age(yr) & $30-50$ & $31-53$ \\
\hline Male & 70 & 75 \\
\hline Female & 30 & 25 \\
\hline Weight(Kg) & $50-62$ & $51-65$ \\
\hline $\begin{array}{c}\text { Duration of } \\
\text { anaesthesia(min) }\end{array}$ & $120 \pm 8.2$ & $123 \pm 7.5$ \\
\hline
\end{tabular}

The gargled ketamine group of patients had weight from 30 to 50 years. In this group 70 males and 30 females were present. The weight of the patients ranges from 50 to $62 \mathrm{~kg}$. The duration of anaesthesia is $120 \pm 8.2$ minutes.

The Nebulised Ketamine group patients had a age in between 31-53 years. This group of patients includes the 75 males and 25 females. The weight of the patients ranges from $51-65 \mathrm{~kg}$. The deration of anaesthesia is $123 \pm 7.5$ mins.

Table 2: Comparison of the Grading discomfort over study duration in both study group

\begin{tabular}{|c|c|c|c|c|c|c|c|c|}
\hline- & \multicolumn{2}{|c|}{ Ohrs } & \multicolumn{2}{|c|}{ 2hrs } & \multicolumn{2}{|c|}{ 4hrs } & \multicolumn{2}{|c|}{24 hrs } \\
\hline $\begin{array}{l}\text { Grading of } \\
\text { discomfort }\end{array}$ & $\begin{array}{c}\text { A: Gargled } \\
\text { Ketamine }\end{array}$ & $\begin{array}{c}\text { B: } \\
\text { Nebulised } \\
\text { Ketamine }\end{array}$ & $\begin{array}{c}\text { A: Gargled } \\
\text { Ketamine }\end{array}$ & $\begin{array}{c}\text { B: } \\
\text { Nebulised } \\
\text { Ketamine }\end{array}$ & $\begin{array}{c}\text { A: } \\
\text { Gargled } \\
\text { Ketamine }\end{array}$ & $\begin{array}{c}\text { B: } \\
\text { Nebulised } \\
\text { Ketamine }\end{array}$ & $\begin{array}{c}\text { A: } \\
\text { Gargled } \\
\text { Ketamine }\end{array}$ & $\begin{array}{c}\text { B: } \\
\text { Nebulised } \\
\text { Ketamine }\end{array}$ \\
\hline No sore throat & 72 & 80 & 76 & 83 & 80 & 88 & 90 & 93 \\
\hline Mild sore throat & 24 & 16 & 16 & 15 & 13 & 10 & 10 & 8 \\
\hline $\begin{array}{c}\text { Moderate sore } \\
\text { throat }\end{array}$ & 8 & 8 & 8 & 3 & 8 & 3 & 0 & 0 \\
\hline $\begin{array}{c}\text { Severe sore } \\
\text { throat }\end{array}$ & 0 & 0 & 0 & 0 & 0 & 0 & 0 & 0 \\
\hline $\begin{array}{c}\text { Total no of } \\
\text { patients having } \\
\text { Postoperative } \\
\text { sore throat }\end{array}$ & 28 & 20 & 24 & 18 & 20 & 13 & 40 & 8 \\
\hline
\end{tabular}

The table 2 indicates the Comparison of the Grading discomfort over study duration in both study groups. The data showed that the nebulized ketamine offered more relief in sore throat.
Post operative sore throat, a common complication of general anaesthesia contributes to postoperative morbidity in the patients. Along with causing discomfort to the patient, it prolongs 
the post-operative stay by 14 minutes compared with people who did not complain of $\mathrm{POST}^{[2]}$ The overall incidence of POST is 21- 65\% ${ }^{[3-5]}$ Many studies have shown that gargling with ketamine prior to induction is one of the effective means of reducing the incidence and severity of POST by $50 \%$ and only one study on pre induction nebulised ketamine had shown decreased in the incidence of POST. The present study is done to compare the effectiveness of preoperative ketamine gargle with preoperative ketamine nebulisation in reducing the incidence and severity of POST.

Higgins et al ${ }^{[2]}$ showed in their study that use of succinylcholine increases the incidence of POST due to sarcolemmal tears during fasciculation's. Because of this we avoided succinylcholine in our study.

Pre-operative ketamine nebulisation is comparable with ketamine gargle in reducing the incidence and severity of post-operative sore throat.

\section{REFERENCES}

1. El-Boghdadly K, Bailey CR, Wiles MD. Postoperative sore throat: a systematic review. Anaesthesia. 2016 Jun;71(6):70617. doi: 10.1111/anae.13438. Epub 2016 Mar 28.

2. Higgins $P$ P, Chung F, Mezei G. Postoperative sore throat after ambulatory surgery. Br J Anaesth 2002;88:582-4.

3. Hardy F E, Chung F. Postoperative sore throat: cause, prevention and treatment. Anaesthesia 1999;54:444-53.

4. Christensen A M, Willemoes L H, Lundby L, Jacobsen K B. Postoperative throat complaints after tracheal intubation. $\mathrm{Br} \mathrm{J}$ Anaesth 1994;73:786-7.

5. Loeser E A, Bennett G M, Orr D L, Stanley $\mathrm{T}$ H. Reduction of postoperative sore throat with new endotracheal tube cuffs. Anesthesiology 1980;52: 257-9. 